Jap. J. Ornithol. 45: 187-190, 1996

\title{
Sexual Size Dimorphism and Sex Determination of a Brown Shrike subspecies, Lanius cristatus superciliosus
}

\author{
Masaoki TAKAGI
}

A majority of Laniinae species are sexually dimorphic (GRIME 1985). Some of them have conspicuous sexual dimorphism in plumage, e.g., Bull-headed Lanius bucephalus, Thick-billed L. tigrinus (Yamashina 1934), Gray-backed Fiscal L. excubitorius, and Common Fiscal L. Collaris Shrikes (ZACK \& LIGON 1985). In contrast, Brown Shrikes L. cristatus, which breeds in the Temperate and sub Frigid-Zone in Asia (HowARD \& MoORE 1980), is one of the sexually inconspicuous species in plumage (YAMASHINA 1934, KIYosu 1965, but see TAKAGI in press). So, it has been difficult to determine the sex of this species when no incubation patch exists. Thus, I describe the sexual differences in terms of the morphological traits of a Brown Shrikes subspecies, L. c. superciliosus breeding in Hokkaido, and report a discriminant function analysis using external characteristics designed to discriminate sex.

The study was conducted in Oyafuru $\left(43^{\circ} 13^{\prime} \mathrm{N}, 141^{\circ} 20^{\prime} \mathrm{E}\right)$ about $15 \mathrm{~km}$ north of Sapporo. Nineteen males and sixteen females of $L$. c. superciliosus subspecies were captured using mist-nets from May through July in 1992-1996. Sex was determined by the presence of an enlarged incubation patch, because only females incubate the eggs in Brown Shrikes (Haneda \& TaKahashi 1967). Since Brown Shrikes could not be distinguished by age during the breeding season, data for individuals in each sex were combined in this paper. It was suggested that any differences in plumage among age classes could be discounted (see TAKAGI in press). Nine characters were measured to the nearest $0.01 \mathrm{~mm}$ using vernier calipers as described by Yamashina (1934), Svensson (1984) and TAKAGI (in press). These characteristics were the following: (1) length of unflattened wing chord, (2) tail length, (3) tarsus length, (4) bill length, length from the tip of the bill to the feathering, (5) bill depth, (6) width at the posterior edge of nostril, (7) length of gape, (8) length of total head, the maximum length from the tip of the bill to the back of the skull, and (9) width of white band on forehead. Body mass was determined by a digital platform, or a balance, to the nearest $0.1 \mathrm{~g}$. I used a discriminant function analysis for sex determinaiton. In the analysis, total head length was excluded, as the number of individuals for which total head length was measured was insufficient. Body mass was also excluded, because measuring of mass in each individual were not conducted in a same breeding stage. It has been shown in Loggerhead Shrikes that, due to the fluctuation in body mass during a breeding season, mass could not be used for descriminat analysis (Collister \& Wicklum 1996). Statistical and discriminant function analyses were performed by using STATISTICA ${ }^{\otimes}$ (THREE'S COMPANY. INC.).

Males were significantly larger than females for tail length and width of white band on forehead, although considerable overlaps in range occurred (Table 1). Body mass of females was significantly heavier than of males (Table 1). There was no significant difference in length of wing chord or in size of skeletal parts between sexes (Table 1).

I performed liner discriminant analyses between sexes using the single variables, tail length and width of white band on forehead showing significant sexual differences, separately. Using discriminant analysis with variable tail length, 84.2\% (16 /19) of the males and $75 \%(12 / 16)$ of the females were correctly identified. Using this 
Table 1. Morphological measurements $(\mathrm{mm})$ and body mass $(\mathrm{g})$ in Brown Shrikes during breeding season.

\begin{tabular}{lrrrr:rrrr|rr}
\hline & \multicolumn{4}{c|}{ Male } & \multicolumn{4}{c|}{ Female } & \multicolumn{2}{c}{ t-test } \\
\cline { 2 - 13 } & Mean & SD & Range & $\mathrm{n}$ & Mean & SD & Range & $\mathrm{n}$ & t-value & P-value \\
\hline Wing length & 88.1 & 1.9 & $83.3-91.2$ & 19 & 87.4 & 2.0 & $85.4-89.6$ & 16 & 1.08 & NS \\
Tail length & 86.6 & 2.3 & $84.6-93.6$ & 19 & 83.3 & 2.7 & $82.1-91.0$ & 16 & 3.9 & 0.005 \\
Tarsus length & 24.0 & 0.6 & $22.8-25.0$ & 19 & 23.9 & 0.7 & $22.9-25.4$ & 16 & 0.39 & NS \\
Bill length & 15.6 & 0.5 & $14.8-16.4$ & 18 & 15.7 & 0.7 & $15.2-16.7$ & 16 & -0.52 & NS \\
Bill depth & 8.0 & 0.2 & $7.7-8.3$ & 18 & 8.0 & 0.2 & $7.5-8.4$ & 16 & 0.26 & NS \\
Bill width & 5.8 & 0.3 & $5.3-6.4$ & 18 & 5.9 & 0.3 & $5.6-6.4$ & 16 & -0.83 & NS \\
Length of gape & 22.4 & 0.6 & $21.5-23.4$ & 16 & 22.1 & 0.9 & $21.6-23.8$ & 16 & 1.25 & NS \\
Length of total head & 41.3 & 0.5 & $40.7-42.2$ & 9 & 40.5 & 0.8 & $40.5-41.9$ & 10 & 2.33 & NS \\
Width of white band on forehead & 6.7 & 1.6 & $3.5-10.5$ & 19 & 3.3 & 0.8 & $2.6-4.3$ & 16 & 8.06 & $<0.000$ \\
Body mass & 30.1 & 2.7 & $27.4-34.3$ & 19 & 34.0 & 4.0 & $28.0-37.2$ & 14 & -3.34 & 0.002 \\
\hline
\end{tabular}

Sample sizes for the analysis of each character differed according to the dimensions measured, as it was not obtained for several individuals.

analysis with width of the white band on the forehead, $89.5 \%(17 / 19)$ of the males and $93.8 \%(15 / 16)$ of the females were correctly identified. In both sexes, width of white band on forehead was a better discriminator of sex than tail length.

In order to distinguish sexes more precisely, a multivariate discriminant function analysis was performed. To exclude the effect of multicoliniality caused by highly correlation among variables, I eliminated a variable, length of wing chord, from the analysis, in as much as the correlation coefficient between tail length and length of wing chord was $0.74(P<0.001)$. Correlation coefficients among the other variables were smaller than 0.53 . As a result, seven variables, tail length, tarsus length, length of exposed culmen, bill depth, bill width, gape, and width of the white band on forehead were included in the analysis. To simplify the function, yet keep high discriminant power, I performed an increasing stepwise discriminant analysis. Consequently, two variables, width of white band on forehead and tail length, were selected. The discriminant function is as follow;

$\mathrm{Z}=23.8-0.66 \mathrm{x}_{1}+0.24 \mathrm{x}_{2}(F=40.28, d f s=2,29, P<0.0001) \quad($ Fig. 1)

$\mathrm{x}_{1}$ : length of white band on forehead (WB), $\mathrm{x}_{2}$ : tail length (TL).

The two variables contributed to the function signficantly (WB; $F=34.3, d f s=1,29$, $P<0.0001$, TL; $F=7.80, d f s=1,29, P=0.009)$. When the equation is applied to an individual, $0<\mathrm{Z}$ and $\mathrm{Z}<0$ represent female and male, respectively. The discriminant scores overlapped in $0.59<\mathrm{Z}>0.99$. The probability in discriminating males was $89.5 \%$ $(17 / 19)$, females was $100 \%$ (16/16), and for both sexes was $94.3 \%$. These percentages are within the upper range of percentages yielded in previous research studies of sex discrimination with other avian species, which varid from 77.4-98\% (BoRToloTTI 1984, Murata et al. 1988, Pépin 1985, Charadine \& Morris 1989, Makamura et al. 1989, Collister \& WiCKLUm 1996). Hence, the function of stepwise analysis containing two variables was applicable to sex determination in $L$. c. superciliosus.

Because they have not yet develop an incubation patch when L. c. superciliosus 


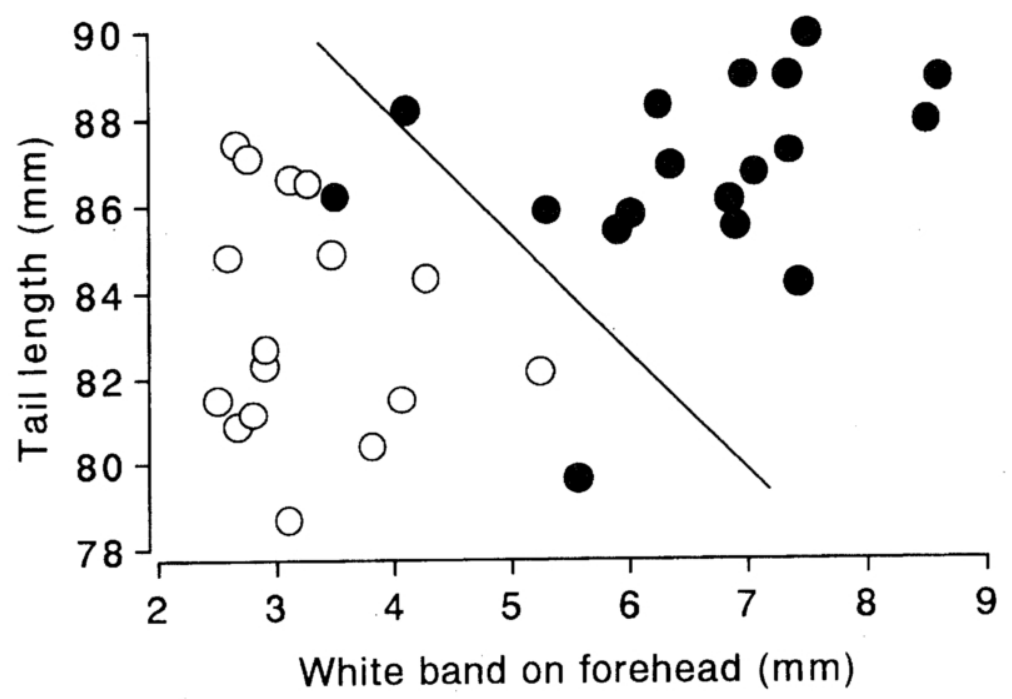

Fig. 1. Relationship between width of white band on forehead and tail length. - and $\bigcirc$ show males and females, respectively. The line $(Z=O, Z=23.8-$ $\left.0.66 \mathrm{x}_{1}+0.24 \mathrm{x}_{2}\right)$ illustrates the boundary which separates males from females.

females first arrive at their breeding ground, their sex can not be identified. Hence, the discriminant function is useful for sex determination in L. c. superciliosus, especially in the early breeding season. I was unable to ascertain whether or not the equation could be applied to sex detemination during the period from post- to pre-breeing molts. Because L. c. superciliosus molt completely during the pre-breeding season (Medway 1970, Stresemann \& Stresemann 1971), they must have already gotten fresh plumage in the breeding season.

I am greatly indebted to Drs. H. Abe, Y. Watanuki, and Y. Saito for their variable comments and criticism of this manuscripts. I also express my thanks to the Bird Migration Research Center, Yamashina Institute for Ornithology, for its kind supporting of my bird banding research.

LITERATURE CITED. BortolotTi, G. R., 1984. Sexual size dimorphism and age-related size variation in Bald Eagles. J. Wildl. Manage. 48: 72-81. OCharadine, J. W. \& MorRis, R. D., 1989. Sexual size dimorphism and assortative mating in the Brown Noddy. Condor 91: 868-874. - Coldister, D. M. \& Wicklum, D. 1996. Intraspecific variation in Loggerhead Shrikes: Sexual dimorphism and implication for subspecies classification. Auk 113: 221-223. Grime, L. G. 1985. Shrike. Campbell, B \& Lack, E. (eds.) A Dictionary of Birds: 534-536. T \& A Poyser, Calton. HANEdA, K \& TAKAHASHI, Y., 1967. Life history of the Japanese Red-tailed Shrike (Lanius cristatus supercil-iosus). I. Breeding Season. Jap. J. Ecol. 18: 47-56. (in Japanese with English summary) Howard, R. \& MoORE, A., 1980. A complete checklist of the birds of the world. Oxford Univ. Press, Oxford. KIyosu, Y., 1965. The birds of Japan. Kodansha, Tokyo. (in Japanese) Medway, L., 1970. A ringing study of the migratory Brown Shrike in west Malaysia. Ibis 112: 184-198. Murata, K., Suzuki, T., Yasufuku, M. \& 
Yoshitake, W., 1988. Sex determination in Manchurian Crane Grus japonensis by discriminant analysis. J. Yamashina. Inst. Ornith. 20: 101-106. (In Japanese with English abstract) ONakamura, K., Sato, F., Sugimori, F. \& Imamura, T., 1989. Sex determination based on external morphological measurements in Brwon-eared Bulbul Hypsipetes amaurotis. J. Yamashina Inst. Ornith 21: 253-264. (In Japanese with English abstract) PÉPIN, D., 1985. Morphological characteristics and sex classification of Red-legged Partidge. J. Wildl. Manage. 49: 228-237. - Stresemann, E. \& Stresemann, V., 1971. Die postnuptial und die praenuptiale Vollmauser der asiatischen Würger Lanius tigrinus und L. cristatus. J. für Orn. 112: 373-395. (in German with English summry) - Svensson, L., 1984. Identification guide to European passerines. 3ed rev. ed. Stockholm. TTAKagi, M., (in press). A sexual difference in plumage of Brown Shrikes, subspecies Lanius cristatus supercilious. J. Yamashina. Inst. Ornithol. - Yamshina, Y., 1934. A natural history of Japanese birds. Azusashobo, Tokyo. (in Japanese). ZZACK, S. \& Ligon, J. D., 1985. Cooperative breeding in Lanius Shrikes. I. Habitat and demography of two sympatric species. Auk 102: 754-765.

アカモズ雌雄の外部計測値における差異と雌雄判別。 アカモズは羽色の性的二型が不明瞭なので, 形態計測值の雌雄比較, および判別分析による雌雄判別を試みた。調查は1992 1996年の $5 \sim 7$ 月に 北海道石狩郡で行なった。抱卵斑の有無によって性判別をしたアカモズの雄19個体, 倠16個体につい て, 10箇所の外部形態の計測, および体重測定を行なった. その結果, 尾長と額の白色带の幅は雄で 有意に長い傾向が認められたが, 自然翼長, ふしょ長, 露出嘴峰長, 嘴高長, 嘴幅長, 口角長, 全頭 長には有意な雌雄差は認められなかった。

計測值間で高い相関関係が認められなかった 6 変数, すなわち尾長, ふしょ長, 露出嘴峰長, 嘴高 長, 嘴幅長, 額の白色带の幅を説明変数として, 変数増加式の多变量線形判別分析を行なった。 その 結果, 尾長と額の白色帯の幅の 2 変数が選択され, 以下の判別式が得られた.

$Z=23.8-0.66 \mathrm{x}_{1}+0.24 \mathrm{x}_{2}(F=40.28, d f s=2.29, P<0.0001)$

$\mathrm{x}_{1}$ は尾長 $(\mathrm{mm}), \mathrm{x}_{2}$ は白色帯の幅 $(\mathrm{mm})$ を示し, 判別值 $\mathrm{Z}<0$ で雄, $\mathrm{Z}>0$ で雌として判別される. この判別式を用いたときの雄の判別率は $89.5 \%$, 雌の判別率は100\%, 両性では $94.3 \%$ ありり, 雌雄の 判別がほぼ可能であることがわかった。繁殖地に渡来したばかりの雌は抱卵斑を発達させていないの で，その時期の雌雄の識別にこの判別式は効果的である.

一一高木昌興

Author's address: Laboratory of Applied Zoology, Faculty of Agriculture, Hokkaido University Sapporo 060, Japan 北海道大学農学部応用動物学教室 T060 札幌市北区北 9 条西 9 丁目 